\title{
Integrating Form and Content within Classroom Discussions of Literature: A Discernible Advantage in Language Learning
}

\begin{abstract}
As both form-focused (FFI) and content-based (CBI) instructions have advantages and disadvantages in language teaching, the integration of FFI and CBI into literature-based classrooms provides an ideal context to attend to form and meaning and some of the strongest rationales for language acquisition as the disadvantages of one approach will be compensated by the advantages of the other. When FFI and CBI are integrated in conjunction with literaturebased approach, learners easily perceive language patterns in the meaningful context, foster content learning and initiate production of the meaningful discourse. Simply put, the advancement of grammatical accuracy and content unveils improvements in language proficiency. The present study aimed to create a favorable condition for language learning through employing FFI and CBI incorporated in a literature-based program. Quasi-experimental approach was adopted and the participants were 60 students majoring in English Language Teaching at a university. It was found that this integrative pedagogy can be used as a springboard for language proficiency development because learners exhibited notable progress in enhancing their grammar and vocabulary knowledge.
\end{abstract}

Keywords: form-focused instruction, content-based instruction, integration, language development, accuracy

\section{Introduction}

The principle of integrating language and content learning is a favorable condition for language learning for its advantages to offer a substantial amount of language input, engage learners into more interaction and provide 
output in meaningful communicative contexts (Lo, 2014). The process of interaction brings about receiving modified input while learners process negotiation of meaning (Mackey \& Oliver, 2002), taking cognizance of target language features through noticing (Gass \& Mackey, 2007), and pushing learners for more language output (Swain, 1995) that results in language development. The acquisition of linguistic forms through instructional interventions enables learners to use the language with greater fluency and accuracy (Spada \& Lightbown, 2008).

It should be noted that in the failure of form and meaning balance language learning does not spawn successful outcomes. The inclusion of form-focused instruction in a content-enriched language instruction through using literary works offers learners discernible advantages. Literature gives a basis for group discussions; thus, it has communicative value (Mart, 2018; Mart, 2019a; Shanahan, 1997). Moreover, literature discussions have the potential to help learners notice language forms and integrate the knowledge into communicative activities (Mart, 2019b; Nystrand, 2006). This study has been designed to draw learners' attention to form and meaning simultaneously through integrating form-focused and content-based approaches by means of literature discussions to make real gains in grammar and vocabulary learning.

\section{Literature Review}

\section{Form-Focused Instruction}

Empirical support for form-focused instruction (FFI) comes from several studies investigating its role in communicative use of language (Larsen-Freeman \& Long, 1991; Ellis, 2008; Ranta \& Lyster, 2018). Spada (1997) bestows promising evidence for the potency of FFI and defined the approach as "any pedagogical effort which is used to draw the learners' attention to form either implicitly or explicitly [...] within meaning-based approaches to L2 instruction in which a focus on language is provided in either spontaneous or predetermined ways" (p. 73). Ellis (2001), on the other hand, defined FFI as "any planned or incidental instructional activity that is intended to induce language learners to pay attention to linguistic form" (pp. 1-2) that embodies not only traditional but also communicative approaches. For Ellis, Basturkmen, and Loewen (2001; 2002), the form includes grammar, vocabulary, discourse, and phonology.

Following Long (1991), FFI is comprised of two types: focus-on-forms and focus-on-form. The former involves intensive treatment of pre-selected specific features based on a linguistic syllabus. The primary focus of attention 
in focus-on-forms instruction is on the targeted form (Ellis, Basturkmen, \& Loewen, 2002). It refers to teaching different points of grammar in separate classes (Sheen, 2002), and preselected forms are attended intensively (Ellis, 2001). It is assumed that focus-on-forms is equated with skill learning and arises from cognitive processes (Sheen, 2002). Conversely, in focus-on-form the central focus of attention is on meaning which brings learners' attention to "linguistic elements as they arise incidentally in lessons whose overriding focus is on meaning or communication" (Long, 1991, pp. 45-46). Long (1991) defined focus-on-form as instructional approaches where the emphasis remains on specific linguistic forms during communicative activities. His definition is restricted to pedagogical events that root in meaning-based activities in which certain linguistic forms are not practiced in predetermined ways. The underlying assumption of focus-on-form is that it derives from comprehensible input ensues from natural interaction.

Norris and Ortega (2000) argue that both focus-on-form and focus-on-forms are equally effective. Focus-on-form is an exponent of grammar-problemsolving tasks rather than explicit instruction (Sheen, 2003), because grammar is treated to meet communicative needs of learners. Likewise, focus-on-forms shares the same assumption with focus-on-form that the priority of communication receives a surge of attention. Teaching grammar is compatible with the development of communication skills in the theory of language acquisition. For this reason, it is recommended that grammar should be the object of some sort of intervention when communication breakdown occurs (Doughty \& Varela, 1998).

FFI has been operationalized as proactive or reactive (Lyster, 2015). While proactive FFI refers to pre-planned instruction to render it possible for the learners to use features of target language which are considered difficult to learn with the aid of exposure to input, reactive FFI bears on language production of learners during teacher-student interaction to bring their attention to the target language (Lyster, 2015). Reactive FFI involves "corrective recasting" (Ellis et al., 2002, p. 422), and spontaneous and unplanned attempts (Lyster, 2007) in which corrective feedback for the treatment of learner errors is provided if learner's self-correction does not occur though the error is highlighted by the teacher. Corrective feedback, a type of FFI, has been considered conducive to language learning as learners have the opportunity to correct their errors. A substantial number of studies have showed the beneficial effects of corrective feedback; thus considered effective in fostering noticing (Sheen, 2007; Yang \& Lyster, 2010). Cognitive psychologists are concerned that the provision of corrective feedback interrupts the flow of communication (e.g., Chaudron, 1988); however, this idea has been viewed as a paradox by Lyster (2007) who attests that corrective feedback should be elicited "in the heat of the moment" (p. 137); simply put, when "the error is still active in memory" (DeKeyser, 2007, p. 5). 
Second language instruction involves two different types that differ regarding the timing of attention to form; while in isolated FFI attention to form is separated from communicative instruction, in integrated FFI attention to form is embedded within communicative teaching (Spada et al., 2014). However, isolated FFI is different from focus-on-forms which involves exclusive focus on language structures. Isolated FFI refers to a focus-on-form that is presented separately but it supports communicative practice. Isolated FFI does not refer to meaningless repetition of grammar rules, thus it does not exclude communicatively-based practice.

Both isolated and integrated instructions have different roles in promoting language acquisition. Second language acquisition (SLA) research has explored the effectiveness of instruction whether it involves attention to both form and meaning. Spada et al. (2009) state that theoretical support for integrated FFI is expressed in Long's (1996) "revised interaction hypothesis," Swain and Lapkin's (2002) "meta-talk," and Lyster's (1998) "negotiation of form" constructs in SLA. These three constructs hinge upon the assumption that if learners attend to form within communicative practice, they obtain information concerning language form by virtue of form-meaning connection and use it for expressing messages. Empirical support for integrated FFI can be found in the works of Ellis, Basturkmen, and Loewen (2001); Williams (2005), and Valeo and Spada (2015) in which learners attend to form in communicative classrooms. Conversely, theoretical support for isolated FFI comes from DeKeyser (1998) who argues that grammar instruction should be performed explicitly "to achieve a maximum of understanding, and then should be followed by some exercises to anchor it solidly in the students' consciousness, in declarative form so that it is easy to keep in mind during communicative exercises" (p. 58). Norris and Ortega (2000) pointed to the necessity of teaching language properties directly and concluded that explicit types of FFI are more effective to help learners notice language forms.

Isolated FFI occurs when focus on language form is separated from meaning-based activities in language classes. This approach is mainly concerned with preparing learners for a communicative activity (Spada et al., 2009). Stern (1992) argued that "there is a still a place for a separate analytic language syllabus" (p. 180), although communicative activities have a central role in language teaching methodology. Ellis (2002) asserted that grammar should be taught separately "making no attempt to integrate it with the task-based component" (p. 32). Nevertheless, isolated FFI does not refer to practicing target forms in mechanical drills which are separate from the communicative activities. Rather, it engages learners in communicative practice through drawing their attention to target forms that arise during interaction activities (Spada et al., 2014). Isolated FFI is useful to elucidate misleading similarities between the L1 and L2 and it helps ensure that learners see simple language features that occur frequently 
but are not salient in oral and written language (Spada \& Lightbown, 2008). Isolated FFI includes the assumption that learners need to discover certain target features during communicative activities. Van Patten (1990) suggested that beginner learners cannot concentrate on some aspects of target forms while perceiving the meaning of a text. Information processing theory argues that learners have difficulty in focusing form and meaning simultaneously due to the restricted processing capacity of the human mind (Ellis, 1997).

Integrated FFI is an appropriate approach for complex language features. Studies by DeKeyser (1995) and Robinson (1996) show that compared with easy rules; hard rules, which are difficult to describe, cannot be successfully taught in isolated instruction. Thus, learners learn complex rules better by means of integrated FFI. The potential effectiveness of integrated FFI to instruction for language features in which errors prompt communication breakdowns has been widely addressed; furthermore, learners need isolated FFI to make formmeaning relationships for low salient and low frequent language features which do not have high communicative value, and once learners make form-meaning connections more fluent and accurate use of the language features may be encouraged through integrated FFI (Spada \& Lightbown, 2008). In general, adult learners benefit from instruction and isolated grammatical instruction is more favorable for them (Barkhuizen, 1998). Young learners acquire proficiency in language with little FFI (Spada \& Lightbown, 2008).

\section{Content-Based Approach}

CBI is an umbrella term that refers to a wide array of teaching models which take language teaching as a basis (Valeo, 2013). CBI is defined as the simultaneous study of language and subject matter with the focus on form and sequence of language items imposed by content material (Martel, 2016; Waller, 2018). Stoller (2008) defines CBI as an instructional approach that dedicates itself to language and content-learning objectives. CBI is conceived as "two for one" (Wesche \& Skehan, 2002, p. 221); that is, it rests on the principle that language learning arises with the dual focus of language and content (Netten, 1991). CBI represents the integration of language learning and cognitive development (Lyster, 2011) to create "the requisite motivational basis for communication" (Lyster, 2007, p. 2).

As an instructional framework, CBI has been considered an effective pedagogy for reinforcing language teaching through the use of authentic materials. The utility of authentic content material in language learning has unveiled fulfillment of the study and a sense of accomplishment for learners (GaffieldVille, 1996). A great deal of research has revealed favorable responses toward CBI with regard to its benefits in promoting language learning (Leaver, 1997), 
increasing learner satisfaction (Rodgers, 2006), enhancing content knowledge (Stryker \& Leaver, 1997), facilitating skill learning (Pica, 2002), improving academic achievement (Smit, 2008), and developing motivation and self-confidence (Stryker, 1997).

A major source of support for CBI classes comes from the Natural Approach, which disregarded grammar teaching. In content-based language teaching, language proficiency is gained by learning of subject matter rather than grammar rules or vocabulary lists. CBI is an instructional approach that shifts the focus of the course from language learning to subject matter learning (Leaver \& Stryker, 1989). In other respects, CBI can contextualize language instruction; thus, plunge learners into a rich exposure to form-meaning relationships and render it possible to learn grammar and vocabulary in clusters pertaining the given topics (Wesche \& Skehan, 2002).

A high level of persuasive support for CBI comes from educational and cognitive psychology. Cognitive learning theory, discourse comprehension processing research, depth-of-processing research, expertise research, and motivation attribution and interest research are five research areas that contribute to CBI (Grabe \& Stoller, 1997). Cognitive learning theory is a strong potential rationale that integrates attention to language and content and is based on a learning theory proposed by Anderson (1990) which combines language knowledge development, language usage practice and strategy training to reinforce independent learning. Grabe and Stoller (1997) assert that discourse comprehension processing research has demonstrated that the relatedness and coherence of the information pave the way for improved learning and recall. Additionally, they attest that depth-of-processing research is consistent with CBI because it provides a basis for coherent and meaningful information that makes way for deeper processing and better learning. Expertise research refers to learning that allows learners to reinvest their knowledge in sophisticated problem-solving activities and gain from the challenges that will occur (Bereiter \& Scardamalia, 1993). Interest of learners in the content triggers their motivation and brings about better learning. Research claims that highly motivated learners tend to make more sophisticated elaborations on the materials through seeking connections among sets of information which will ease their recall of information (Tobias, 1994).

Cummins (2000) is particularly interested in the degree of cognitive demand and contextual support rooted in the tasks while language and content integration; in this framework, learners are apt to access the content with less cognitive demand through tasks with a great degree of context while less context is associated with experiencing difficulties in terms of linguistic knowledge. It has been well documented that CBI classes are effective in the development of content knowledge and interpretive skills (Rodgers, 2006). However, one aspect of CBI that is open to discussion is whether it can promote the form- 
meaning connections learners need for the development of expressive abilities. More precisely, in CBI contexts the connection between content knowledge and functional linguistic abilities of learners remains controversial. Seeking explanations, Williams (2001) posited that learners, particularly at lower proficiency levels, concentrate more on understanding the input than the linguistic form in the context. Likewise, VanPatten (1996) supporting this view hypothesized that in the course of input processing, learners attach priority to meaning rather than form. In essence, it appears that semantic processing of input takes precedence over syntactic processing (Swain, 1985). Zeungler and Brinton (1997) in their attempts to show the connection between linguistic form and pragmatic function held that form and function are inextricably linked, thus content learning and language development cannot be distinguished. It appears to be the fact that form and function development of learners occur jointly which is considered as an optimal path to communicate the acquired concepts of the content (Rodgers, 2006).

A number of studies validated the use of $\mathrm{CBI}$ in foreign language acquisition and development and reported that $\mathrm{CBI}$ is a viable approach for the development of content knowledge and expressive skills (Rodgers, 2006). A substantial amount of literature clearly points the significance of content-based instruction due to its potential benefits for academic growth and language proficiency development (Stoller, 2004; Pessoa et al., 2007). Regular curriculum concepts are enriched with academic content to provide a context for language learning (Curtain \& Pesola, 1994). Stoller (2002) states that in content-based instruction language is viewed as a medium for learning content and content is considered as a resource for the mastery of language.

In the pedagogical literature, incorporating form focus into communicative activities has been considerably supported. For instance, Celce-Murcia (1991) advocates combination of language features within communicative activities and argues that "grammar should never be taught as an end in itself but always with reference to meaning, social factors or discourse or a combination of these factors" (pp. 466-467). Correlatively, Brumfit (1984) asserts that learners should not be prevented from combining language forms with language use since feedback that is provided during communicative interaction influences on formal accuracy. The integration of focus on language form into communicative interaction provides an ideal context for learners to attend to language form. The comprehensible input in meaningful interaction is an effective factor for language acquisition (Long, 1996). Language learning through the use of subject matter makes room for language proficiency and academic skill development across a wide range of learners (Pica, 2002). The integration of subject matter knowledge and language forms not only improves learners' content knowledge but also language skills concurrently (Wesche \& Skehan, 2002) which largely contributes to augmenting communication of content (Swain, 1985). 


\section{The Current Study}

\section{Study Purpose and Research Questions}

In this study, all three groups underwent different treatments (form-focused, content-based and mixed approaches) to investigate the role of combining attention to form and meaning. The aim of the current study was to reveal which of the treatment types the study used has the potential to raise the students' ability to master grammar and vocabulary for meaningful communication. It is hypothesized that integrating language and content is an effective inviting way for students to discover language forms during communicative interactions. The study addressed the following research questions:

1) Is teaching form and content in tandem a favorable condition for language learning?

2) Does the integration of form-focused and content-based approaches within classroom discussions of literature provide advantages to enhance grammar and vocabulary learning?

\section{Participants}

The participants in this study were 60 first-year students majoring in English Language Teaching (ELT) at a university in Iraq. Their ages ranged from 19 to 25 years. The students, with a native language other than English, met three hours a week for two months. They were divided into three different classes randomly (each class had 20 students). Based on the proficiency test they had after enrollment, they were placed in the intermediate level of the program. A situation was constructed for the students to engage them in a process of discovery in which they were afforded the opportunity to promote grammatical accuracy development and enhance their vocabulary knowledge. In this study classroom discussions of literature served as an avenue for the students to perceive the features of target structures in contexts and decipher the meanings of unfamiliar words. While articulating their opinions during classroom discussions, the participants underwent different treatment types. The first control group (Group 1) received formfocused instruction. The second control group (Group 2) received contentbased instruction and finally, the experimental group (Group 3) received the instruction that included form-focused and content-based components (see Table 1). 


\section{Research Materials and Procedures}

The reading materials included The Great Gatsby (1990) by Scott Fitzgerald and Lord of the Flies (2003) by William Golding. While the former centers on the differences between social classes and the decline of American dream, the latter delves into civilization and savagery. These two novels were chosen for their appropriate length, accessible language and universal themes. Pre-and post-assessments were viable methods to assess the extent which an educational intervention influence learning. These tools in this study were used to measure students' vocabulary and grammar knowledge. Comparing the amount of pre-existing knowledge on the topic with the learning as a result of the course experience indicated whether the training courses were successful in increasing their knowledge of the training content.

Table 1

Treatment Activities

\begin{tabular}{|c|c|c|c|}
\hline Groups & Methods employed & Treatment activities & Focus on form/meaning \\
\hline Group 1 & $\begin{array}{c}\text { form-focused instruction } \\
+ \\
\text { literature-based instruction }\end{array}$ & $\begin{array}{c}\text { metalinguistic explanation } \\
+ \\
\text { explicit and implicit } \\
\text { corrective feedback }\end{array}$ & form \\
\hline Group 2 & $\begin{array}{c}\text { content-based instruction } \\
+ \\
\text { literature-based instruction }\end{array}$ & $\begin{array}{l}\text { recasts and prompts as } \\
\text { as feedback on meaning }\end{array}$ & meaning \\
\hline Group 3 & $\begin{array}{c}\text { form-focused instruction } \\
+ \\
\text { content-based instruction } \\
+ \\
\text { literature-based instruction }\end{array}$ & $\begin{array}{c}\text { metalinguistic explanation } \\
+ \\
\text { explicit and implicit } \\
\text { corrective feedback }\end{array}$ & $\begin{array}{c}\text { form } \\
+ \\
\text { meaning }\end{array}$ \\
\hline
\end{tabular}

\section{Procedure in Group 1}

Explanations, dialogues, key sentences, and teacher action are components of conventional presentation techniques (Johnson, 1996). In this study, Group 1 received treatment that included grammatical explanations and utterances of students in dialogues. Explicit and implicit corrective feedback helped students with the acquisition of grammar. The researcher used recasts and prompts to draw students' attention to the target forms. Metalinguistic explanations were provided during the treatment instruction. All classroom discussions were on the course content and based on the mastery of language forms but the instruction to Group 1 also included instructions that engage learners in communicative practice. 
The implementation of both explicit and implicit corrective feedback, as displayed in Table 2, during treatment instruction in Group 1 was conducive to the acquisition of grammatical features. The instructor provided implicit feedback in the following example by responding to the learner's error in Group 1. In response to the learner's statement "has became," the instructor replied "has become." Or to put this another way, ill-formed utterance was reformulated by the instructor to encourage the student to use the target forms more accurately. The provision of on-the-spot reformulations by an external source created conditions for learners to elicit self-repair and promoted the level of accuracy in language acquisition. An example of explicit feedback was the instructor's response to the student's error by saying "use present tense consistently." It is important to stress that corrective feedback displayed a significant advantage to repair the errors and produce a modified output.

Student: The beast has became one of the most important goals in the novel.

Teacher: Oh, the beast has become one of the most important symbols in the novel. Can you give an example?

Student: Yes, it has become an important symbol for instance; it has become Jack's source of power.

Teacher: How does Jack use the beast to his advantage?

Student: He used the beast to frighten the other boys.

Teacher: Use present tense consistently

Student: Jack uses the beast to frighten the other boys.

Student: And, he uses the beast for power.

(Classroom Conversation)

\section{Procedure in Group 2}

The instruction in Group 2 did not include references to grammar or metalinguistic explanations. All classroom discussions focused entirely on content because students talk about literature came to the fore in CBI classes and corrective feedback on form was limited to recasts. Recasts were effective to edit the discourse and repair the conversational breakdowns. Lyster and Ranta (1997) argue that learners in CBI classes may perceive recasts as feedback on meaning. In the following example, discussion is used to construct and negotiate knowledge by the discourse contexts of interaction. The instructor provided recasts to stimulate the student to express the meaning precisely in order to seek constructive ways and to express the meaning precisely.

Teacher: How can you explain Gatsby's greedy pursuit of wealth?

Student: He influences Daisy.

Teacher: He wants to impress Daisy. 
Student: Yes, he wants to impress Daisy.

Teacher: Why do you think he wants to impress Daisy?

Student: He wants to impress Daisy. In fact, he wants to get happiness. He has dream of happiness with Daisy.

Teacher: Good point! He is in pursuit of happiness. Let's consider this point a bit further.

(Classroom Conversation)

\section{Procedure in Group 3}

The instruction in Group 3 included metalinguistic explanations and references to grammar in meaningful comprehensible input to promote grammatical accuracy development. Both explicit and implicit corrective feedback was used to maximize language development. Literature discussions are strong potential foundations for grammatically richer intake and meaningful communication establishment. Drawing attention to errors and giving corrective feedback in Group 3, as shown in the following example, provided some of the strongest rationales for students to attend to accuracy in communicative activities. Students in Group 3 made appropriate use of form-meaning connections in literature discussions and had a number of distinct advantages to develop accuracy and fluency.

Teacher: What is the climax in Lord of the Flies?

Student: Simon understood that the beast doesn't exist.

Teacher: He realized that the beast ...

Student: He realized that the beast didn't exist.

Teacher: Good Point!

Teacher: Then what happened to him?

Student: The other boys killed him with savage.

Teacher: They killed him savagely.

Student: Yes, they killed him savagely and problems started on the island.

Teacher: What problems started on the island?

Student: The boys started doing evil things.

Teacher: Savagery prevails on the island.

Student: Yes, after the death of Simon we see big changes and serious problems.

Teacher: Good! Can you explain that a bit more?

Student: The boys were not civilized, they became savage. Although everything started well at the beginning, the control was lost soon. It is like the power of violence charmed the boys.

Teacher: Yes, the lure from civility and the allure of violence

(Classroom Conversation) 
Table 2

Corrective feedback options

\begin{tabular}{ll}
\hline \multicolumn{1}{c}{ Options } & \multicolumn{1}{c}{ Description } \\
\hline Implicit feedback & $\begin{array}{l}\text { The teacher responds to students' ill-formed utterances without } \\
\text { directly indicating that an error has been made through prompts } \\
\text { or recasts. }\end{array}$ \\
\hline Explicit feedback & $\begin{array}{l}\text { The teacher responds to students' ill-formed utterances by directly } \\
\text { indicating that an error has been made through drawing their } \\
\text { attention to them or metalinguistic explanation. }\end{array}$ \\
\hline
\end{tabular}

Table 2 defines the correction feedback options that were used in the study. Both types of feedback options were used in all groups in the classroom discussions of literature. Implicit feedback included responding to the ill-formed utterances of the students indirectly to give them a chance to reformulate their utterances. Explicit feedback included responding to the incorrect utterances by directly indicating that the error should be corrected.

\section{Data Collection and Analysis}

In this study, a pre-test, a post-test and a delayed post-test were conducted to measure language progress of students. Each test consisted of two parts: grammar and vocabulary, and each part included 25 questions. The students were allowed 45 minutes to complete 50 questions in each test and the scores were given out of 100. Each group had the same tests that included multiple-choice and fill-in-the-blank questions. The students were exposed to all sorts of grammar rules and a wide variety of words in the novels. The assessment tests were prepared by the researcher based on the novels the participants read in the classes throughout the study. In other words, the vocabulary and the grammatical constructions derived from the novels were included. The tests did not differ from each other in terms of scope and format. To ensure that the tests were of similar level of difficulty, the researcher asked two of his colleagues, who work at the same department, to work closely with him. The students were not penalized for wrong answers; therefore, they did not leave any questions unanswered. The test outcomes were compared to measure student performance in relation to their vocabulary and grammar development under different treatment conditions. 
Table 3

Timeline for pre- and post-assessments

\begin{tabular}{lll}
\hline Weeks & Groups & Data sources \\
\hline 1 & All groups & Pre-test \\
8 & All groups & Post-test \\
Three months after the study & All groups & Delayed post-test \\
\hline
\end{tabular}

The pre-test was conducted in the first week before the treatment sessions started. In the eighth week, after the treatment sessions were over, the students had the post-test. Finally, delayed post-test was conducted three months after the experiment to determine which treatment measures aided recall.

\section{Findings}

SPSS 20 was used to conduct reliability analysis in the study. Kurtosis and skewness statistics were used to examine the normality of variables. The acceptable range for kurtosis and skewness is between -2 and +2 . The kurtosis and skewness of each variable fell within acceptable limits in the study in all groups. Cronbach's alpha was used to assess the reliability and internal consistency. For a classroom exam, a reliability coefficient of .70 or higher is an acceptable value for Cronbach's alpha. The alpha coefficient for all items in all groups is higher than .94, suggesting that the items have relatively high internal consistency.

Table 4 illustrates the descriptive statistics (minimum, maximum, mean, and standard deviation) for tests for all groups. The results show that students in Group 1 increased their scores on all tests. The means showed high improvement for post-test grammar and delayed-test grammar and increased from 64.0 to 74,8 , and 77 respectively. With regard to vocabulary tests, the means showed slight improvement and increased from 60.4 to 64.8 in the post-test grammar, and 66.4 in the delayed-test grammar.

The results indicate that students in Group 2 increased their scores on all tests. The means showed high improvement for post-test vocabulary and delayed-test vocabulary and increased from 58.9 to 69.9 , and 72.9 respectively. With regard to grammar tests, the means showed slight improvement and increased from 66.1 to 69.3 in the post-test grammar, and 70.8 in the delayed test grammar.

Group 3 increased their scores on all tests. The means showed high improvement for all tests. The means for grammar tests increased from 63.8 to 78.1 in the post-test grammar, and 80.8 in the delayed-test grammar. With regard to vocabulary tests, the means showed improvement and increased from 61.8 to 75.4 in the post-test vocabulary, and 78.8 in the delayed-test vocabulary. 
Table 4

Descriptive statistics for pre-test, post-test and delayed-test for Group 1

\begin{tabular}{llcccc}
\hline \multicolumn{1}{c}{ Types of tests } & N & Minimum & Maximum & Mean & St. Deviation \\
\hline Pre-test Grammar 1 & 20 & 42.0 & 88.0 & 64.0 & 13.50 \\
Pre-test Grammar 2 & 20 & 44.0 & 86.0 & 66.1 & 10.84 \\
Pre-test Grammar 3 & 20 & 40.0 & 78.0 & 63.8 & 10.38 \\
Post-test Grammar 1 & 20 & 52.0 & 92.0 & 74.2 & 11.74 \\
Post-test Grammar 2 & 20 & 52.0 & 88.0 & 69.3 & 9.86 \\
Post-test Grammar 3 & 20 & 50.0 & 94.0 & 79.7 & 12.02 \\
Delayed-test Grammar 1 & 20 & 52.0 & 94.0 & 77.0 & 12.50 \\
Delayed-test Grammar 2 & 20 & 52.0 & 90.0 & 70.8 & 9.78 \\
Delayed-test Grammar 3 & 20 & 48.0 & 96.0 & 82.6 & 14.25 \\
Pre-test Vocabulary 1 & 20 & 40.0 & 80.0 & 60.4 & 11.67 \\
Pre-test Vocabulary 2 & 20 & 40.0 & 76.0 & 58.9 & 10.73 \\
Pre-test Vocabulary 3 & 20 & 40.0 & 78.0 & 61.8 & 10.25 \\
Post-test Vocabulary 1 & 20 & 46.0 & 84.0 & 64.8 & 10.92 \\
Post-test Vocabulary 2 & 20 & 48.0 & 90.0 & 69.9 & 12.30 \\
Post-test Vocabulary 3 & 20 & 46.0 & 92.0 & 75.4 & 11.80 \\
Delayed-test Vocabulary 1 & 20 & 48.0 & 86.0 & 66.4 & 10.92 \\
Delayed-test Vocabulary 2 & 20 & 52.0 & 92.0 & 72.9 & 13.01 \\
Delayed-test Vocabulary 3 & 20 & 46.0 & 94.0 & 78.8 & 13.16 \\
\hline
\end{tabular}

250

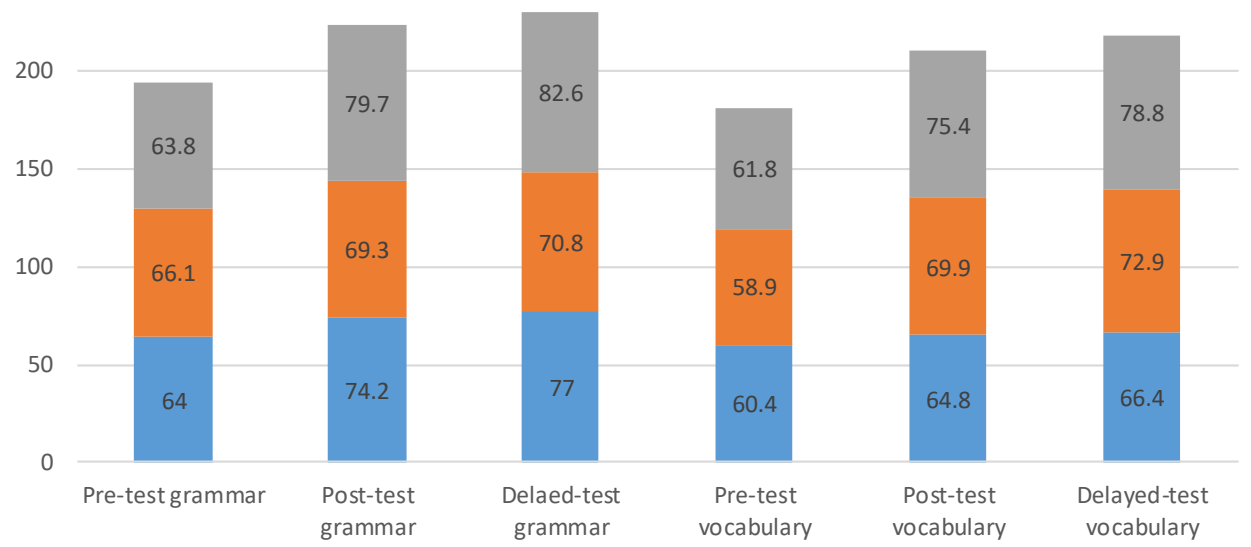

- Group 1 Group 2 aroup 3

Figure 1. Means of pre-test, post-test, and delayed-test grammar and vocabulary for all groups 
Figure 1 displays comparison of means for grammar and vocabulary tests which reveal that students in Group 3 showed better improvement than the other two groups and demonstrated significant gains in scores from pre-test to posttest and maintained this improvement in delayed post-test. Similarly, Group 1 outperformed Group 2 and made significant gains over time in grammar. Group 2 could not make significant gains in grammar tests. Comparison of means for vocabulary tests reveals that students in Group 3 showed better impro-vement than the other two groups and made significant gains between pre-test and post-test. Likewise, Group 2 outperformed Group 1 and made significant gains over time. Group 1 could not make significant gains in vocabulary tests.

A one-way ANOVA revealed statistically significant difference between groups in pre-test and post-test grammar results $(\mathrm{F}(2,57)=6,42, \mathrm{p}=.003)$. Also, there was a statistically significant difference between groups in pre-test and post-test vocabulary results $(\mathrm{F}(2,57)=6,76, \mathrm{p}=.002)$. Bonferroni corrected post hoc tests were run to determine whether the pairwise comparisons were significant. Bonferroni corrected post hoc tests showed that Group 3 demonstrated significantly high difference $(\mathrm{p}=.000)$ compared to Group $1(.002)$ and Group 2 (.003). One-way ANOVA was conducted again to compare the means between delayed-test grammar and delayed-test vocabulary and it was found that there was a statistically significant difference between groups in delayedtest grammar $(\mathrm{F}(2,57)=6,82, \mathrm{p}=.001)$, and delayed-test vocabulary $(\mathrm{F}(2,57)$ $=6,96, p=.000)$. Specifically, these results suggest that treatment received by Group 3 (Mixed Approach) has an effect on the achievement of the participants.

Table 5

Grammar and vocabulary tests group comparison

\begin{tabular}{|c|c|c|c|c|c|c|c|}
\hline \multirow[b]{2}{*}{ Pairs } & \multirow[b]{2}{*}{ Tests } & \multicolumn{2}{|c|}{ Group 1} & \multicolumn{2}{|c|}{ Group 2} & \multicolumn{2}{|c|}{ Group 3} \\
\hline & & $d f$ & P-Value & df & P-Value & df & P-Value \\
\hline \multirow[t]{2}{*}{ Pair 1} & Grammar Pre-test 1 & -14.769 & $19.000^{*}$ & -8.718 & $19.000^{*}$ & -24.430 & $19.000^{*}$ \\
\hline & Grammar Post-test 1 & & & & & & \\
\hline \multirow{2}{*}{ Pair 2} & & -4.222 & $19.000^{*}$ & -2.517 & $19.021^{*}$ & -3.500 & $19.002^{*}$ \\
\hline & Grammar Delayed Post & st 1 & & & & & \\
\hline \multirow[t]{2}{*}{ Pair 1} & Vocabulary Pre-test 1 & -12.815 & $19.000^{*}$ & -15.983 & $19.000^{*}$ & -20.168 & $19.000^{*}$ \\
\hline & Vocabulary Post-test 1 & & & & & & \\
\hline \multirow{2}{*}{ Pair 2} & & -3.238 & $19.000^{*}$ & -5.090 & $19.000^{*}$ & -6.240 & $19.000^{*}$ \\
\hline & Vocabulary Delayed Po & test 1 & & & & & \\
\hline
\end{tabular}

*Significant at $\mathrm{P}<.05$ 
A paired samples t-test revealed a statistically significant difference between pre-test and post-test grammar results in Group 1: $\mathrm{t}(19)=-14.8, \mathrm{p}<.001$; Group 2: $\mathrm{t}(19)=-8.8, \mathrm{p}<.001$; and Group 3: $\mathrm{t}(19)=-24.430, \mathrm{p}<.001$. Similarly, the test revealed a statistically significant difference between post-test and delayed post-test grammar results in Group 1: $\mathrm{t}(19)=-4.222, \mathrm{p}<.001$; Group 2: $\mathrm{t}(19)$ $=-2.517, \mathrm{p}<.05$; and Group 3: $\mathrm{t}(19)=-3.500, \mathrm{p}<.005$.

Also a paired samples t-test indicated that there was a statistically significant difference between pre-test and post-test vocabulary results in Group 1: $\mathrm{t}(19)=-12.815, \mathrm{p}<.001$; Group 2: $\mathrm{t}(19)=-15.983, \mathrm{p}<.001$; and Group 3: $t(19)=-20.168, p<.001$. Similarly, the test revealed a statistically significant difference between post-test and delayed post-test vocabulary results in Group 1: $\mathrm{t}(19)=-3.238, \mathrm{p}<.005$; Group 2: $\mathrm{t}(19)=-5.090, \mathrm{p}<.001$; and Group 3: $\mathrm{t}(19)=-6.240, \mathrm{p}<.001$.

\section{Discussion}

Pre- and post-assessments were conducted to measure students' progress under different treatments. The results of the tests showed that the experimental group (Group 3) which was exposed to mixed-approach made noticeable gains in terms of grammatical and lexical forms compared with the other two groups.

The debate whether grammar instruction in the communicative classroom should be provided or not have posed two extremes: while some advocate minimal attention to grammar, some advocate ample attention and integrate the knowledge into communicative activities (Sheen, 2002). In the realm of the language classroom, some linguistic features are acquired without guided attention; conversely, it is evident that some linguistic features do not develop in the absence of intentional effort (Spada \& Lightbown, 2008). The study shows that FFI treatment in Group 2 outperformed CBI treatment in Group 3 on the grammar component. It has been suggested by linguists and practitioners alike that some form of grammatical instruction should be included in language programs because a lack of grammatical accuracy is an obstacle for not developing native-like abilities in written or oral language proficiency (Millard, 2000). Production of correct and advanced language and appropriate use of language units help language learners keep interactions going; therefore, promotes their access to language input (Krashen, 1982). There is a growing consensus that some language features do not appear in learners' use of language without FFI (Spada \& Lighbown, 2008). When criteria by Long (1991) and Norris and Ortega (2000) are followed, it is feasible that they emphasize on both the need for communication and form-oriented instruction. 
Another issue to point out is that CBI treatment in the study is more effective than FFI treatment on the vocabulary component. Nation and Webb (2011) argue that CBI provides clear advantages for vocabulary learning. The core premise of Communicative Language Teaching is that learners need a reason to talk, in other words learners should be provided a genuine purpose in which the emphasis is on information exchange and meaning negotiation by utilizing meaningful contexts (Millard, 2000). Further, as Brown (1994) stresses, language is spoken at the discourse level rather than sentence level because meanings are not acquired from isolated individual sentences but from "referents in both previous sentences and following sentences" (p. 235). However, it is uncommon for language learners to arrive at high levels of linguistic competence from engaging in entirely meaning-focused instruction. When grammar scores of CBI treatment are examined, it is noticed that they seemed to lack language accuracy. Swain (1993) discovered that without exposure to language forms, simply learning in context does not lead to real gains in achieving the desired outcomes in proficiency level. In a meaning-based classroom "learners are usually not specifically taught the strategies, maxims and organizational principles that govern communicative language use but are expected to work these out for themselves through extensive task engagement" (Celce-Murcia, Dörnyei, \& Thurrell, 1997, p. 141) because meaning-based instruction aims to enhance ability of learners to communicate in real-life settings. This engagement provides learners with an ample amount of target language samples that may develop their sociolinguistic, discourse, strategic and linguistic competence (Barrot, 2014). However, the sufficiency of meaning-focused instruction has been questioned (Long, 1996; Larsen-Freeman \& Long, 1991). For instance, Swain (1995) proposes that learners not only involve in communicative language use but also attend to form to master the language. In Doughty's (2001) view, "the factor that distinguishes focus-on-form from other pedagogical approaches is the requirement that focus on form involves learners' briefly and perhaps simultaneously attending to form, meaning and use during one cognitive event" (p. 211) as FFI helps learners make more efficient use of linguistic forms in meaningfocused language use. The acquisition of linguistic forms through exposure to instructional intervention enables learners to use the language with greater fluency and accuracy (Spada \& Lightbown, 2008).

Treatment 3 was shown to be effective in that the learners made measurable gains on both grammar and vocabulary components. The inability of communicative ESL teaching alone has led to providing implicit focus on grammar during communicative language teaching without revival of traditional grammar-based language instruction in the EFL situation (Fotos, 1998; Fotos \& Hinkel, 2007). EFL syllabus design, in which the entire lesson content comprises grammar points, is ineffective. Long (1988) notes that teaching grammatical forms in 
isolation, fails to advance learners' ability to utilize forms for communicative language use. Correspondingly, he suggests that communicative syllabus which neglects grammar instruction is inadequate in EFL pedagogy. Thus, combining communicative language use with grammar instruction provides for learners clear advantages to perceive the characteristics of target structures in context and improve their accuracy (Fotos, 1998; Baecher, Farnsworth, \& Ediger, 2014; Zarobea \& Cenoz, 2015). Also, it was seen that the students were able to retain newly acquired knowledge for a long time when form and content was integrated in the language classroom.

\section{Conclusion}

The present study has highlighted the premise that the integration of FFI and CBI within classroom discussions of literature is a powerful approach to help learners make form-meaning connections and measurable gains in language learning outcomes. FFI draws attention of learners to target features to reach high levels of linguistic competence. The acquisition of linguistic forms provides clear advantages for language learners to perceive the characteristics of target structures in context and use the language with greater accuracy. CBI is the simultaneous study of language and content. CBI provides optimal conditions for language learning in which learners use the target language as a medium of communication rather than a means of instruction for analysis. Content-based classrooms provide language learners occasions to negotiate form and meaning and promote their knowledge. Language learners construct knowledge and negotiate through the discourse contexts of interaction. CBI situates the comprehensible input at the core of language acquisition. Any content material that addresses to the cognitive needs of learners and with the language input can be used to develop their language skills and, at the same time, help them become knowledgepowered individuals. The impetus of CBI to impact verbal interaction of language learners motivates them for successful outcomes. An integrated approach which focuses on both form and content led to real gains in language learning. The study revealed that collaborating FFI and CBI within classroom discussions of literature is an optimal path for language learners to attend to language forms within communicative practice and creates them occasions to negotiate form and meaning. The provision of language forms in meaning-based tasks is an optimal path for language learners to achieve the desired outcomes for language proficiency development through building grammar and vocabulary knowledge. 


\section{Limitations of the Study}

The number of participants and materials in the study is limited. A large sample size would reveal more accurate information; thereby, the study calls for further investigation with an increased number of participants and materials to have better insights into the effectiveness of literature discussions in the language classroom on speech production. The present study used novels in discussions. Further research would be truly beneficial in which different literary genres are used to measure gains of students in the development of language proficiency.

\section{References}

Anderson, J. R. (1990). Cognitive psychology and its implications. New York: Freeman.

Baecher, H., Farnsworth, T., \& Ediger, A. (2014). The challenges of planning language objectives in content-based ESL instruction. Language Teaching Research, 18(1), 118-136.

Barkhuizen, G. P. (1998). Discovering learners' perceptions of ESL classroom teaching/learning activities in a South African context. TESOL Quarterly, 32, 85-108.

Barrot, J. S. (2014). Combining isolated and integrated form-focused instruction: Effects on productive skills. Language, Culture and Curriculum, 27(3), 278-293.

Bereiter, C., \& Scardamalia, M. (1993). Surpassing ourselves: An inquiry into the nature and implications of expertise. Chicago: Open Court.

Brown, H. D. (1994). Teaching by principles: An interactive approach to language pedagogy. Englewood Cliffs, NJ: Prentice-Hall.

Brumfit, C. J. (1984). Communicative methodology in language teaching. Cambridge: Cambridge University Press.

Chaudron, C. (1988). Second language classrooms: Research on teaching and learning. New York: Cambridge University Press.

Celce-Murcia, M. (1991). Grammar pedagogy in second and foreign language teaching. TESOL Quarterly, 25(3), 459-480.

Celce-Murcia, M., Dörnyei, Z., \& Thurrell, S. (1997). Direct approaches in L2 instruction: A turning point in communicative language teaching? TESOL Quarterly, 31, 141-152.

Cummins, J. (2000). Language, power and pedagogy: Bilingual children in the crossfire. Buffalo, NY: Multilingual Matters

Curtain, H., \& Pesola, C. A. B. (1994). Languages and children: Making the match, foreign language instruction for an early start grades $K-8$. White Plains, NY: Longman.

DeKeyser, R. (1995). Learning second language grammar rules: An experiment with a miniature linguistic system. Studies in Second Language Acquisition, 17, 379-410.

DeKeyser, R. (1998). Beyond focus on form: Cognitive perspectives on learning and practising second language grammar. In C. Doughty \& J. Williams (Eds.), Focus on form in classroom second language acquisition (pp. 42-63). Cambridge University Press, New York. 
DeKeyser, R. (2007). Introduction: Situating the concept of practice. In R. DeKeyser (Ed.), Practice in a second language: Perspectives from applied linguistics and cognitive psychology (pp. 1-18). Cambridge, UK: Cambridge University Press.

Doughty, C., \& Varela, E. (1998). Communicative focus on form. In C. Doughty \& J. Williams (Eds.), Focus on form in classroom second language acquisition (pp. 114-138). Cambridge: Cambridge University Press.

Doughty, C. J. (2001). Cognitive underpinnings of focus on form. In P. Robinson (Ed.), Cognition and second language instruction (pp. 206-257). New York: Cambridge University Press.

Ellis, N. C. (1997). Vocabulary acquisition, word structure, collocation, word-class, and meaning. In N. Schmitt \& M. McCarthy (Eds.), Vocabulary: Description, acquisition and pedagogy (pp. 122-139). Cambridge: Cambridge University Press.

Ellis, R. (2001). Introduction: Investigating form-focused instruction. Language Learning, 51 (Supplement 1), 1-46.

Ellis, R. (2002). The place of grammar instruction in the second/foreign language curriculum. In E. Hinkel \& S. Fotos (Eds.), New perspectives on grammar teaching in second language classrooms (pp. 17-34). Mahwah, NJ: Lawrence Erlbaum.

Ellis, R., Basturkmen, H., \& Loewen, S. (2001). Learner uptake in communicative ESL lessons. Language Learning, 51, 281-318.

Ellis, R., Basturkmen, H., \& Loewen, S. (2002). Doing focus-on-form. System, 30, 419-432.

Ellis, R. (2008). The study of second language acquisition (2nd ed.). Oxford: Oxford University Press.

Fitzgerald, F. S. (1990). The Great Gatsby. London: Penguin Books.

Fotos, S. (1998). Shifting the focus from forms to form in the EFL classroom. ELT Journal, 52(4), 301-307.

Fotos, S., \& Hinkel, E. (2007). Form-focused instruction and output for second language writing gains. In S. Fotos \& H. Nassaji (Eds.), Form-focused instruction and teacher education: Studies in honour of Rod Ellis. Oxford: Oxford University Press.

Gaffield-Ville, N. (1996). Content-based second language instruction at the tertiary level. ELT Journal, 50, 108-114.

Gass, S. M., \& Mackey, A. (2007). Input, interaction and output in second language acquisition. In J. Williams \& B. VanPatten (Eds.), Theories in second language acquisition (pp. 175-199). Mahwah, NJ: Lawrence Erlbaum.

Golding, W. (2003). Lord of the flies. New York: Perigee.

Grabe, W., \& Stoller, F. L. (1997). Content-based instruction: Research foundations. In M. A. Snow \& D. M. Brinton (Eds.), The content-based classroom: Perspectives on integrating language and content (pp. 5-21). NY: Longman.

Johnson, K. (1996). Language teaching and skill learning. Oxford, UK: Blackwell.

Krashen, S. (1982). Principles and practice in second language acquisition. Oxford: Pergamon Press.

Larsen-Freeman, D., \& Long, M. H. (1991). An introduction to second language acquisition research. New York, NY: Longman.

Leaver, B. L. (1997). Content-based instruction in a basic Russian program. In S. B. Stryker \& B. L. Leaver (Eds.), Content-based instruction in foreign language education: Models and methods (pp. 31-55). Washington, DC: Georgetown University Press.

Leaver, B. L., \& Stryker, S. B. (1989). Content-based instruction for language classrooms. Foreign Language Annals, 22(3), 269-275.

Lo, Y. Y. (2014). L2 learning opportunities in different academic subjects in content-based instruction - Evidence in favour of "conventional wisdom." Language and Education, 28(2), 141-160. 
Long, M. (1988). Focus on form: A design feature in language teaching methodology. Presentation given at the National Foreign Language Center European Cultural Foundation Conference on Empirical Research on Second Language Learning in Institutional Settings. Bellagio, Italy, June 20-24. Mimeo.

Long, M. (1991). Focus on form: A design feature in language teaching methodology. In K. de Bot, R. Ginsberg, \& C. Kramsch (Eds.), Foreign Llnguage research in crosscultural perspective (pp. 39-52). Amsterdam: John Benjamins.

Long, M. (1996). The role of the linguistic environment in second language acquisition. In W. Ritchie \& T. Bhatia (Eds.), Handbook of second language acquisition (pp. 413-468). San Diego, CA: Academic Press.

Lyster, R. (1998). Negotiation of form, recasts, and explicit correction in relation to error types and learner repair in immersion classrooms. Language Learning, 48, 183-218.

Lyster, R. (2007). Learning and teaching languages through content: A counterbalanced approach. Amsterdam: John Benjamins.

Lyster, R. (2011). Content-based second language teaching. In E. Hinkel (Ed.), Handbook of research in second language teaching and learning, vol. 2 (pp. 611-630). New York: Routledge.

Lyster, R. (2015). Using form-focused tasks to integrate language across the immersion curriculum. System, 54, 4-13.

Lyster, R., \& Ranta, L. (1997). Corrective feedback and learner uptake: Negotiation of from in communicative classrooms. Studies in Second Language Acquisition, 2037-2066.

Mackey, A., \& Oliver, R. (2002). Interactional feedback and children's L2 development. System, 30(4), 459-477.

Mart, Ç. T. (2018). Literature in the language classroom: A recipe to maximize learning. L1 Educational Studies in Language and Literature, 18, 1-25.

Mart, Ç. T. (2019a). Reader-response theory and literature discussions: A springboard for exploring literary texts. The New Educational Review, 56, 78-87.

Mart, Ç. T. (2019b). A comparison of form-focused, content-based and mixed approaches to literature-based instruction to develop learners' speaking skills. Cogent Education, 6, 1-27.

Martel, J. (2016). Three foreign language student teachers' experiences with content-based instruction: Exploring the identity/innovation interface. Innovation in Language Learning and Teaching, 1-13.

Millard, D. J. (2000). Form-focused instruction in communicative language teaching: Implications for grammar textbooks. TESL Canada Journal, 18(1), 47-57.

Nation, I. S. P., \& Webb, S. (2011). Content-based instruction and vocabulary learning. In E. Hinkel, (Ed.), Handbook of research in second language teaching and learning (vol. 2) (pp. 631-665). New York: Routledge Company.

Netten, J. (1991). Towards a more language oriented second language classroom. In L. Malave \& G. Duquette (Eds.), Language, culture and cognition (pp. 284-304). Clevedon: Multilingual Matters.

Norris, J. M., \& Ortega, L. (2000). Effectiveness of L2 instruction: A research synthesis and quantitative meta-analysis. Language Learning, 50(3), 417-528.

Nystrand, M. (2006). Research on the role of classroom discourse as it affects reading comprehension. Reading Research Quarterly, 46(8), 392-412.

Pessoa, S., Hendry, H., Donato, R., Tucker, G. R., \& Lee, H. (2007). Content-based instruction in the foreign language classroom: A discourse perspective. Foreign Language Annals, 40(1), 102-121.

Pica, T. (2002). Subject-matter content: How does it assist the interactional and linguistic needs of classroom language learners? The Modern Language Journal, 86(1), 1-19. 
Ranta, L., \& Lyster, R. (2018). Form-focused-instruction. In P. Garrett \& J. Cots (Eds.), The Routledge handbook of language awareness (pp. 40-56). New York: Routledge.

Robinson, P. (1996). Learning simple and complex second language rules under implicit, incidental, rule-search and instructed conditions. Studies in Second Language Acquisition, 19, 233-247.

Rodgers, D. M. (2006). Developing content and form: Encouraging evidence from Italian content-based instruction. The Modern Language Journal, 90(3), 373-386.

Savignon, S. J. (Ed.). (2002). Interpreting communicative language teaching: Contexts and concerns in teacher education. New Haven: Yale University Press.

Shanahan, D. (1997). Articulating the relationship between language, literature, and culture: Toward a new agenda for foreign language teaching and research. The Modern Language Journal, 81(2), 164-174.

Sheen, R. (2002). Focus on form and focus on forms. ELT Journal, 56(3), 303-304.

Sheen, R. (2003). Focus on form - A myth in the making? ELT Journal, 57(3), 225-233

Sheen, Y. (2007). The effects of corrective feedback, language aptitude and learner attitudes on the acquisition of English articles. In A. Mackey (Ed.), Conversational interaction in second language acquisition: A collection of empirical studies (pp. 301-322). Oxford: Oxford University Press.

Smit, U. (2008). Research in progress. The AILA research network, CLIL and immersion classrooms: Applied linguistics perspectives. Language Teaching, 41(2), 295-298.

Spada, N. (1997). Form-focused instruction and second language acquisition: A review of classroom and laboratory research. Language Teaching, 30(2), 73-87.

Spada, N., Barkaoui, K., Peters, C., So, M., \& Valeo, A. (2009). Developing a questionnaire to investigate second language learners"e preferences for two types of form-focused instruction. System, 37, 70-81.

Spada, N., Jessop, L., Tomita, Y., Suzuki, W., \& Valeo, A. (2014). Isolated and integrated form- focused instruction: Effects on different types of L2 knowledge. Language Teaching Research, 18(4), 453-473.

Spada, N., \& Lighbown, P. M. (2008). Form-focused instruction: Isolated or integrated? TESOL Quarterly, 42(2), 181-207.

Stern, H. H. (1992). Issues and options in language teaching. Oxford: Oxford University Press.

Stoller, F. (2002). Promoting the acquisition of knowledge in a content based course. In J. Crandall \& D. Kaufman (Eds.), Content-based instruction in higher education settings (pp. 109-123). Alexandria, VA: TESOL.

Stoller, F. (2004). Content-based instruction: Perspectives on curriculum planning. Annual Review of Applied Linguistics, 24, 261-283.

Stoller, F. L. (2008). Content-based instruction. In N. Van Deusen-Scholl \& N. H. Hornberger (Eds.), Encyclopedia of language and education, vol. 4: Second and Foreign Language Education (pp. 59-70). New York: Springer.

Stryker, S. B. (1997). The Mexico experiment at the foreign service institute. In S. B. Stryker \& B. L. Leaver (Eds.), Content-based instruction in foreign language education: Models and methods (pp. 177-202). Washington, DC: Georgetown University Press.

Stryker, S. B., \& Leaver, B. (1997). Content-based instruction in foreign language education. Washington, D.C.: Georgetown University Press.

Swain, M. (1985). Communicative competence: Some roles of comprehensible input and comprehensible output in its development. In S. Gass \& C. Madden (Eds.), Input in second language acquisition (pp. 235-253). New York, NY: Newbury House.

Swain, M. (1993). The output hypothesis: Just speaking and writing aren't enough. Canadian Modern Language Review, 50(1), 158-164. 
Swain, M. (1995). Three functions of output in second language learning. In G. Cook \& B. Seidlhofer (Eds.), Principle and practice in applied linguistics: Studies in honour of H. G. Widdowson (pp. 125-144). Oxford: Oxford University Press.

Swain, M., \& Lapkin, S. (2002). Talking it through: Two French immersion learners' responses to reformulation. International Journal of Educational Research, 37, 285-304.

Tobias, S. (1994). Interest, prior knowledge, and learning. Review of Educational Research, 64(1), 37-54.

Valeo, A. (2013). The integration of language and content: Form-focused instruction in a contentbased language program. The Canadian Journal of Applied Linguistics, 16(1), 25-50.

Valeo, A., \& Spada, N. (2015). Is there a better time to focus on form? Teacher and learner views. TESOL Quarterly, 50(2), 314-339.

VanPatten, B. (1990). Attending to content and form in the input: An experiment in consciousness. Studies in Second Language Acquisition, 12, 287-301.

VanPatten, B. (1996). Input processing and grammar instruction in second language acquisition. Norwood, NJ: Ablex.

Waller, T. A. (2018). Content-based instruction. The TESOL Encyclopedia of English Language Teaching, 1-5.

Wesche, M. B., \& Skehan, P. (2002). Communicative, task-based and content-based language instruction. In R. B. Kaplan (Ed.), The Oxford handbook of applied linguistics (pp. 227-228). Oxford: Oxford University Press.

Williams, J. (2001). The effectiveness of spontaneous attention to form. System, 29, 325-340.

Williams, J. (2005). Form-focused instruction. In E. Hinkel (Ed.), Handbook on research in second language teaching and learning (pp. 673-691). Mahwah, NJ: Lawrence Erlbaum Associates.

Yang, Y., \& Lyster, R. (2010). Effects of form-focused practice and feedback on Chinese EFL learners' acquisition of regular and irregular past tense forms. Studies in Second Language Acquisition, 32, 235-263.

Zarobe, Y., \& Cenoz, J. (2015). Way forward in the twenty-first century in content-based instruction: Moving towards integration. Language, Culture and Curriculum, 28(1), 90-96.

Zeungler, J., \& Brinton, D. M. (1997). Linguistic form, pragmatic function: Relevant research from content-based instruction. In M. A. Snow \& D. M. Brinton (Eds.), The Content-based classroom: Perspectives on integrating language and content (pp. 263-273). White Plains, NY: Longman.

Çağrı Tuğrul Mart

\title{
Die Integration von Form und Inhalt in den Diskussionen über die Literatur in einer Klasse mit erweitertem Fremdsprachenunterricht
}

\author{
Zusammenfassung
}

In Anbetracht dessen, dass sowohl das Unterrichten von formalen Aspekten (engl. form-focused instruction), als auch das inhaltsorientierte Unterrichten einer Fremdsprache (engl. content-focused instruction) bestimmte Vor- und Nachteile aufweisen, gewährleistet die Integration der beiden Unterrichtskonzepte und deren Einbeziehung in einen auf literarischen Texten basierten Fremdsprachenunterricht aufgrund ihrer gegenseitigen Komplementarität 
einen idealen Kontext. Solche Methode ermöglicht den Schülern, Sprachmuster in einem Kontext zu erkennen und einen sinnvollen Diskurs auszulösen. Darüber hinaus hat sie einen positiven Einfluss auf den Fachunterricht. Das Ziel der dargestellten Untersuchung war es, eine Diagnose zu stellen, wie effektiv das Fremdsprachenlernen durch die Integration von formalen Aspekten und der Inhaltsorientierung im Fremdsprachenunterricht im Falle eines literaturbasierten Lehrprogramms sein kann. An dieser quasi-experimentellen Untersuchung nahmen 60 Studierende eines Lehrerstudiums teil (Englisch als Fremdsprache). Es wurde festgestellt, dass die integrative Methode als Werkzeug für die Entwicklung von Sprachkompetenzen dienen kann, weil die Schüler wesentliche Fortschritte in Bezug auf die Erweiterung ihrer grammatischen und lexikalischen Kenntnisse aufweisen.

Schlüsselwörter: Unterrichten von formalen Aspekten einer Fremdsprache, das inhaltsorientiere Unterrichten, Integration, Sprachentwicklung, Korrektheit 